\title{
Pengaruh Pupuk Nanosilika Terhadap Jumlah Stomata, Kandungan Klorofil dan Pertumbuhan Padi Hitam (Oryza sativa L. cv. japonica)
}

\section{The Effect Nanosilica Fertilizer on Numbers of Stomata, Chlorophyll Content, and Growth of Black Rice (Oryza sativa L. cv. Japonica)}

\author{
Fevi Mawadhah Putri ${ }^{1^{*}}$, Sri Widodo Agung Suedy ${ }^{2}$, Sri Darmanti ${ }^{2}$ \\ ${ }^{1}$ Program Studi Biologi, Departemen Biologi, Fakultas Sains dan Matematika, Universitas Diponegoro \\ ${ }^{2}$ Departemen Biologi, Fakultas Sains dan Matematika, Universitas Diponegoro \\ Jl. Prof. H. Soedharto, SH, Tembalang, Semarang \\ *Email: fevimawadhah@gmail.com
}

Diterima 21 Desember 2016/Disetujui 18 Februari 2017

\begin{abstract}
ABSTRAK
Tanaman padi membutuhkan silika lebih banyak dari pada tanaman lainnya, sementara lahan pertanian di Indonesia banyak yang mengalami leaching unsur hara mikro termasuk Si.Unsur hara Si untuk tanaman padi selama ini hanya didapat dari keberadaannya di lahan sawah dan tidak dilakukan penambahan dari luar, hal ini menyebabkan ketersediaan Si akan terus berkurang dari waktu ke waktu, untuk mengatasi hal tersebut perlu dilakukan pemupukan silika. Penggunaaan pupuk silika dalam bentuk nano lebih menguntungkan bagi tanaman karena lebih reaktif, distribusi lebih merata dan langsung mencapai target, serta hanya dibutuhkan dalam jumlah sedikit. Penelitian ini bertujuan menganalisis pengaruh pemberian pupuk nanosilika terhadap jumlah stomata,kandungan klorofil dan pertumbuhan padi hitam (Oryza sativa L. cv. Japonica). Penelitian ini dilakukan menggunakan Rancangan Acak Lengkap (RAL) satu faktor, yaitu konsentasi pupuk nanosilika dengan lima taraf perlakuan:0 ml/L;2,5 ml/L; $5 \mathrm{ml} / \mathrm{L} ; 7,5 \mathrm{ml} / \mathrm{L} ; 10 \mathrm{ml} / \mathrm{L}$.Data yang diperoleh dianalisis menggunakanAnalisys of Variance (ANOVA) dan dilanjutkan dengan uji jarak berganda Duncan's Multiple Range Test(DMRT) pada taraf kepercayaan 95\%. Hasil penelitian menunjukkan bahwa pemberian pupuk nanosilika dengan konsentrasi 7,5 ml/L dapat meningkatkan pertumbuhan yaitu; jumlah stomata sebesar 142 $\%$, tinggi tanaman sebesar 33\% dan tebal daun sebesar 100\% dibandingkan kontrol. Namun pemberian pupuk nanosilika tidak berpengaruh nyata terhadap jumlah anakan, bobot basah, bobot kering dan kandungan klorofil.
\end{abstract}

Kata kunci: beras hitam, nanosilika, pertumbuhan, stomata, klorofil

\begin{abstract}
Rice crop requires more silica than other plants, while the agricultural land in Indonesia suffered micro nutrients leaching including Si. Silica nutrients for the rice crop had only obtained from wetland and no replenishment from the outside, this led to the availability of $\mathrm{Si}$ will continue to decrease over time. Therefore, to overcome this need is necessary silica fertilization. The use of silica fertilizerin nano sizemore profitable for the plant because more reactive, more equitable distribution, achieve the target directly, and only needed in little doses. This study aimed to analyze the effect of fertilizer nanosilika the number of stomata, chlorophyll and the growth of black rice (Oryza sativa L. cv. Japonica). This research was conducted using a Completely Randomized Design (CRD) one factor, that is nanosilika concentration with five treatments: $0 \mathrm{ml} / \mathrm{L} ; 2.5 \mathrm{ml} / \mathrm{L}$; $5 \mathrm{ml} / \mathrm{L} ; 7.5 \mathrm{ml} / \mathrm{L} ; 10 \mathrm{ml} / \mathrm{L}$.The data was analized by Analysis of Variance (ANOVA) and continued with multiple range test Duncan's Multiple Range Test (DMRT) at 95\% confidence level. These results indicate that fertilizer nanosilika with a concentration of $7.5 \mathrm{ml} / \mathrm{L}$ could increase the growth; $142 \%$ number of stomata, $33 \%$ of plant height and $100 \%$ of leaf thickness than the control treatment. However nanosilika fertilizer application did not significantly affect the number of tillers, wet and dry weight, and chlorophyll content.
\end{abstract}

Keywords : black rice, nanosilica, growth, stomata, chlorophyll 


\section{PENDAHULUAN}

Indonesia memiliki banyak varietas padi, salah satunya adalah padi hitam (Oryza sativa $\mathrm{L}$. cv. japonica).Beras hitam merupakan salah satu jenis beras yang mulai populer di masyarakat dan dikonsumsi sebagai pangan fungsional yang bermanfaat bagi kesehatan karena kaya akan nutrisi seperti asam amino, kalium, magnesium, kalsium, zat besi, pigmen antosianindan flavonoid sehingga dapat meningkatkan daya tahan tubuh terhadap penyakit, memperbaiki kerusakan sel hati, mencegah gangguan fungsi ginjal, mencegah kanker, memperlambat penuaan, sebagai antioksidan, membersihkan kolesterol dalam darah, dan mencegah anemia (Suhartini dan Suardi, 2010).Varietas padi hitam belum banyak dikenal masyarakat, sehingga pemanfaatannya masih sangat terbatas, baik dalam kegiatan konsumsi, produksi, maupun kegiatan pemuliaannya. Saat ini budidaya padi hitam oleh petani masih kurang, disebabkan karena umur budidaya yang relatif panjang, hasil yang rendah dan sangat disukai oleh burung (Kristamtini, 2009).

Jenis pupuk atau unsur hara yang hampir tidak pernah diberikan atau ditambahkan ke dalam tanah pada pertanian tanaman padi adalah silika. Tanaman padi membutuhkan silika lebih banyak dari pada tanaman lainnya, sementara lahan pertanian di Indonesia banyak yang mengalami leaching unsur hara mikro termasuk Si. Kandungan Si tersedia di dalam tanah sawah tidak berbanding lurus dengan kandungan totalnya (Husnain, 2011). Selama ini, unsur hara Si hanya didapat dari keberadaannya di lahan sawah dan tidak dilakukan penambahan dari luar, hal ini menyebabkan ketersediaan $\mathrm{Si}$ akan terus berkurang dari waktu ke waktu sehingga tanaman padi akan kekurangan unsur $\mathrm{Si}$ dan dapat mengakibatkan pertumbuhan dan produktivitas tanaman padi kurang optimal, karena unsur $\mathrm{Si}$ memiliki peran penting pada tanaman padi (Amrullah, 2015). Oleh karena itu, perlu dilakukan pemupukan silika terutama dalam bentuk nano agar kebutuhan Si untuk tanaman padi hitam dapat tercukupi. Pemupukan silika terutama dalam bentuk nano memiliki keunggulan lebih reaktif, langsung mencapai target karena ukurannya yang kecil, serta hanya dibutuhkan dalam jumlah yang sedikit (Aryanto, 2012).

Tanaman Graminae seperti padi, jagung, dan tebu sangat membutuhkan unsur hara $\mathrm{Si}$ terutama di permukaan daun, batang, dan gabah (padi). Unsur Si dapat menstimulasi fotosintesis dan translokasi karbon dioksida $\left(\mathrm{CO}_{2}\right)$. Silika yang terakumulasi pada daun padi berfungsi menjaga daun tetap tegak sehingga membantu penangkapan cahaya matahari dalam proses fotosintesis dan translokasi $\mathrm{CO}_{2}$ ke malai. Unsur $\mathrm{Si}$ juga dapat mengurangi cekaman abiotik, seperti suhu, radiasi cahaya, angin, air, dan kekeringan, serta meningkatkan resistensi tanaman terhadap cekaman biotik, seperti serangan penyakit dan hama. Pemberian Si pada tanaman secara umum dapat memperbaiki fungsi fisiologi, menguatkan jaringan dan meningkatkan ketahanan tanaman terhadap serangan hama dan penyakit sehingga meningkatkan pertumbuhan dan produksi tanaman (Husnain, 2011).Pertumbuhan dan perkembangan dipengaruhi oleh proses metabolisme tanaman yang meliputi proses fotosintesis, respirasi dan transpirasi.Laju fotosintesis adalah tolak ukur pertumbuhan yang berkaitan dengan produksi tanaman (Ningsih dkk, 2012).

Stomata merupakan organ penting dalam proses fotosintesis dan juga transpirasi pada tanaman. Stomata berfungsi sebagai tempat pertukaran $\mathrm{CO}_{2}$ di daun untuk proses fotosintesis dan sebagai tempat penguapan air dalam proses transpirasi. Hasil penelitian yang dilakukan oleh Arista dkk, (2015) pada tanaman tebu menunjukkan bahwa pemberian silika dapat meningkatkan kerapatan stomata yang menyebabkan jumlah stomata semakin banyak, sehingga dapat meningkatkan laju transpirasi dan penyerapan $\mathrm{CO}_{2}$ untuk fotosintesis.

Klorofil termasuk salah satu bagian penting pada proses fotosintesis dalam sel tanaman yang berfungsi menyerap cahaya untuk menghasilkan energi. Hasil penelitian yang dilakukan oleh Avila et al. (2010) menunjukkan bahwa pemberian silika dapat meningkatkan kandungan klorofil tanaman padi. 
Peningkatan jumlah stomata dan kandungan klorofil tanaman menyebabkan laju fotosintesis juga meningkat sehingga dapat merangsang proses pertumbuhan.

\section{METODE PENELITIAN}

Penelitian ini dilakukan di laboratorium BSFT Jurusan Biologi, Fakultas Sains dan Matematika, Universitas Diponegoro Semarang.

Benih padi yang digunakan pada penelitian ini yaitu benih padi hitam cempo ireng yang berasal dari Sleman Yogyakarta.

Seleksi dan perkecambahan benih, pemilihan benih yang baik dilakuan dengan cara direndam dalam air kemudian dipilih benih yang tenggelam, setelah itu direndam selama 24 jam dan diperam selama 24 jam untuk perkecambahan.

Persiapan media semai, media semai dimasukkan kedalam ember plastik dan diberi air secukupnya hingga teksturnya menyerupai tanah sawah. kemudian dipindahkan kedalam nampan hingga penuh.

Persemaian benih, benih yang telah diseleksi disemaikan diatas nampan yang berisi media semai selama 21 hari.

Persiapan media tanam, tanah sawah dimasukan kedalam ember plastik dengan diameter $31 \mathrm{~cm}$ hingga terisi $2 / 3$ dari tinggi ember.

Pengukuran faktor lingkungan, faktor lingkungan yang diukur adalah $\mathrm{pH}$ dan kelembapan dengan menggunakan soil tester.

Pemindahan dan penanaman, benih padi yang berumur 21 HSS (Hari Setelah Semai) dipindahkan kedalam media tanam secara hatihati, kemudian ditanam pada masing-masing ember sebanyak empat tanaman.

Pemupukan dasar, pemupukan dilakukan sebanyak dua kali mengacu pada penelitian Wangiyana (2009) yaitu: I pada umur 7 HST dengan pupuk Urea, TSP dan $\mathrm{KCl}$ sebanyak $0,9 \mathrm{~g}$; $0,7 \mathrm{~g}$ dan $0,7 \mathrm{~g}$ (masing-masing setara dengan 250 , 100 dan $100 \mathrm{~kg} / \mathrm{ha}$ ); II pada umur 25 HST dengan pupuk urea sebanyak $0,9 \mathrm{~g}$ untuk setiap ember.

Pemupukan Si, pemupukan dilakukan dengan cara pupuk disemprotkan pada seluruh permukaan sampai tanaman basah merata, pada saat tanaman berumur 10, 20, 30, 40, 50 HST dengan 5 taraf konsentrasi yaitu P0 $0 \mathrm{ml} / \mathrm{L}$; P1 2,5 $\mathrm{ml} / \mathrm{L}$; P2 $5 \mathrm{ml} / \mathrm{L} ;$ P3 7,5 ml/L; P4 $10 \mathrm{ml} / \mathrm{L}$ per masing-masing perlakuan dengan volume yang sama yaitu sebanyak $10 \mathrm{ml}$ (setara dengan dosis anjuran 5 tutup botol/tangki).

Pemeliharaan, pengairan tanaman dilakukan dengan penggenangan maksimal $2 \mathrm{~cm}$ di atas permukaan tanah setiap 2 hari sekali atau pada saat kondisi media tanam sudah kering sampai tanaman berumur 50 HST. Penyiangan gulma dilakukan secara manual apabila terdapat gulma yang tumbuh. Pengendalian hama/penyakit dilakukan pada saat tanaman diserang hama/penyakit dengan cara memberikan pestisida yang tepat.

Pengamatan, parameter yang diamati yaitu jumlah stomata, kandungan klorofil dan pertumbuhan tanaman.

Perhitungan jumlah stomata tanaman padi hitam umur 50 HST dilakukan dengan fotomikrograf pada luas area tertentu menggunakan preparat irisan segar membujur daun tanaman padi hitam.

Analisis kandungan klorofil dilakukan dengancara sampel helaian daun untuk tiap perlakuan diambil dan ditimbang sebanyak $0,25 \mathrm{~g}$ lalu dipotong kecil-kecil. Potongan daun ini kemudian diekstrak menggunakan aceton $80 \%$ sebanyak $25 \mathrm{ml}$ dengan cara menggerusnya didalam lumpang hingga klorofilnya terlarut semua. Larutan tersebut kemudian disaring dengan menggunakan kertas saring dan hasil saringan dimasukkan kedalam labu ukur $25 \mathrm{ml}$. Larutan kemudian dimasukkan kedalam kuvet dan dianalisis dengan spektrofotometer pada panjang gelombang $663 \mathrm{~nm}$ dan $645 \mathrm{~nm}$. Hasilnya dihitung dengan metode Arnon (1949):

Klorofil a $(\mathrm{mg} / \mathrm{g})=[12,7 \times \mathrm{A} 663-2,69 \times \mathrm{A} 645]$

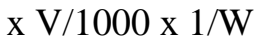

Klorofil b (mg/g) $=[22,9 \times$ A645 - 4,86 x A663 $]$ x $\mathrm{V} / 1000 \times 1 / \mathrm{W}$

Dimana V adalah volume dari ekstrak (ml) dan W adalah bobot basah dari sampel (gr). Pengamatan pertumbuhan dilakukan sejak awal pindah tanam sampai tanaman berumur 50 HST. Tinggi tanaman dan jumlah anakan padi diukur setiap 10hari sekali, untuk bobot basah dan bobot 
keringdiukur pada umur 50 HST. Tebal daun diukur pada tanaman yang berumur 50 HST dengan fotomikrograf menggunakan preparat irisan segar melintang daun tanaman padi hitam.

\section{HASIL DAN PEMBAHASAN}

Data hasil penelitian pengaruh pemberian pupuk nanosilika pada tanaman padi hitam terhadap jumlah stomata, kandungan klorofil dan pertumbuhan tanaman dapat dilihat pada tabel 1 .
Hasil analisis ANOVA terhadap jumlah jumlah stomata menunjukkan hasil yang beda nyata sedangkan untuk kandungan klorofil menunjukkan hasil yang tidak berbeda nyata. Hasil analisis ANOVA terhadap parameter pertumbuhan pada variabel tinggi tanaman dan tebal daun menunjukkan hasil yang beda nyata, sedangkan pada variabel jumlah anakan, bobot basah dan bobot kering menunjukkan hasil yang tidak berbeda nyata.

Tabel 1. Rerata jumlah stomata dan kandungan klorofil tanaman padi hitam umur 50 HST setelah pemberian pupuk nanosilika dengan konsentrasi yang berbeda.

\begin{tabular}{cccc}
\hline Perlakuan & $\begin{array}{c}\text { Jumlah Stomata/5904, } \\
413 \mu \mathrm{m}^{2}\end{array}$ & $\begin{array}{c}\text { Kandungan Klorofil } \\
\mathrm{a}(\mathrm{mg} / \mathrm{g})\end{array}$ & $\begin{array}{c}\text { Kandungan Klorofil } \\
\mathrm{b}(\mathrm{mg} / \mathrm{g})\end{array}$ \\
\hline P0 $(0 \mathrm{ml} / \mathrm{L})$ & $3,33^{\mathrm{d}}$ & 1,24 & 0,45 \\
P1 $(2,5 \mathrm{ml} / \mathrm{L})$ & $6,67^{\mathrm{b}}$ & 1,39 & 0,53 \\
P2 $(5 \mathrm{ml} / \mathrm{L})$ & $5,33^{\mathrm{c}}$ & 1,38 & 0,49 \\
P3 $(7,5 \mathrm{ml} / \mathrm{L})$ & $8,00^{\mathrm{a}}$ & 1,59 & 0,56 \\
P4 $(10 \mathrm{ml} / \mathrm{L})$ & $4,33^{\mathrm{cd}}$ & 1,26 & 0,44 \\
\hline
\end{tabular}

Keterangan : Angka yang diikuti oleh huruf yang sama pada kolom yang sama berbeda tidak nyata berdasarkan uji Duncan pada taraf kepercayaan $95 \%$.

Tabel 2. Rerata tinggi tanaman (cm), jumlah anakan (batang/rumpun), bobot basah $(\mathrm{g})$, bobot kering $(\mathrm{g})$ dan tebal daun $(\mu \mathrm{m})$ padi hitam umur $50 \mathrm{HST}$ setelah pemberian pupuk nanosilika dengan konsentrasi yang berbeda.

\begin{tabular}{lccccc}
\hline Perlakuan & $\begin{array}{c}\text { Tinggi } \\
\text { Tanaman } \\
(\mathrm{cm})\end{array}$ & $\begin{array}{c}\text { Jumlah Anakan } \\
\text { (batang/rumpun })\end{array}$ & $\begin{array}{c}\text { Bobot Basah } \\
(\mathrm{g})\end{array}$ & $\begin{array}{c}\text { Bobot kering } \\
(\mathrm{g})\end{array}$ & $\begin{array}{c}\text { Tebal daun } \\
(\mu \mathrm{m})\end{array}$ \\
\hline P0 $(0 \mathrm{ml} / \mathrm{L})$ & $53,00^{\mathrm{r}}$ & 36,67 & 318,47 & 77,51 & $100,16^{\mathrm{z}}$ \\
P1 $(2,5 \mathrm{ml} / \mathrm{L})$ & $65,67^{\mathrm{pq}}$ & 38,67 & 326,35 & 81,33 & $137,14^{\mathrm{xyz}}$ \\
P2 $(5 \mathrm{ml} / \mathrm{L})$ & $67,03^{\mathrm{pq}}$ & 39,67 & 356,48 & 92,95 & $172,57^{\mathrm{xy}}$ \\
P3 $(7,5 \mathrm{ml} / \mathrm{L})$ & $70,67^{\mathrm{p}}$ & 43,00 & 335,11 & 85,14 & $201,05^{\mathrm{x}}$ \\
P4 $(10 \mathrm{ml} / \mathrm{L})$ & $61,67^{\mathrm{q}}$ & 38,67 & 321,89 & 77,64 & $126,47^{\mathrm{yz}}$ \\
\hline
\end{tabular}

Keterangan: Angka yang diikuti oleh huruf yang sama pada kolom yang sama berbeda tidak nyata berdasarkan uji Duncan pada taraf kepercayaan 95\%.

Hasil jumlah stomata pada Tabel 1 menunjukkan bahwa pemberian pupuk nanosilika pada tanaman padi hitam dapat meningkatkan jumlah stomata.Perlakuan P1, P2 dan P3 menunjukkan pengaruh yang nyata terhadap kontrol. Pemberian pupuk nanosilika dapat meningkatkan jumlah stomata sebesar $142 \%$ dibandingkan dengan kontrol.

Hal ini menunjukkan bahwa silika berperan dalam proses diferensiasi sel. Diferensiasi merupakan salah satu bentuk adaptasi tumbuhan untuk menyesuaikan fungsinya dengan lingkungan. Meningkatnya jumlah stomata merupakan proses adaptasi tanaman terhadap kondisi lingkungannya. Tanaman yang diberi perlakuan pupuk nanosilika memiliki ukuran stomata yang lebih besar dibandingkan dengan kontrol (Tabel 3).

Meningkatnya ukuran stomata menyebabkan kerapatannya juga meningkat 
sehingga terjadi peningkatan jumlah stomata tanaman padi hitam pada satuan luas tertentu. Silika yang terdapat pada daun membuat tanaman memiliki daun yang tegak dan merentang dengan baik sehingga bisa mengurangi dampak ternaungi, hal ini membuat tanaman mendapatkan intensitas cahaya yang tinggi sehingga penyerapan cahaya matahari lebih optimal dan menyebabkan jumlah stomata meningkat. Peningkatan jumlah stomata dapat diasumsikan sebagai bentuk adaptasi tanamanterhadap lingkungan sekitar akibat dari kebutuhan penguapan yang lebih besar.

Tabel 3. Rerata Ukuran Stomata $(\mu \mathrm{m})$ Tanaman Padi Hitam

\begin{tabular}{lcc}
\hline Perlakuan & $\begin{array}{c}\text { Panjang } \\
(\mu \mathrm{m})\end{array}$ & $\begin{array}{c}\text { Lebar } \\
(\mu \mathrm{m})\end{array}$ \\
\hline $\mathrm{P} 0(0 \mathrm{ml} / \mathrm{L})$ & 11,84 & 17,88 \\
$\mathrm{P} 1(2,5 \mathrm{ml} / \mathrm{L})$ & 15,07 & 20,83 \\
$\mathrm{P} 2(5 \mathrm{ml} / \mathrm{L})$ & 17,36 & 19,37 \\
$\mathrm{P} 3(7,5 \mathrm{ml} / \mathrm{L})$ & 17,41 & 20,08 \\
$\mathrm{P} 4(10 \mathrm{ml} / \mathrm{L})$ & 14,37 & 21,07 \\
\hline
\end{tabular}

Panjang dan lebar stomata berkaitan erat dengan ukuran porus stomata, semakin besar ukuran stomata maka porus stomata juga akan semakin besar. Hal ini mengakibatkan tingginya laju transpirasi karena air yang keluar lebih banyak sehingga akan meningkatkan serapan unsur hara dari dalam tanah. Unsur hara yang diserap akan digunakan untuk proses fotosintesis yang menyebabkan peningkatan laju fotosintesis yang akan berpengaruh pada meningkatnya pertumbuhan dan perkembangan tanaman.

Hasil kandungan klorofil pada Tabel 1 menunjukkan bahwa pemberian pupuk nanosilika dapat meningkatkan kandungan klorofil a dan klorofil b. Hal ini dikarenakan silika secara tidak langsung berperan dalam sintesis klorofil. Silika di dalam tanaman akan yang terakumulasipada daun padi berfungsi menjaga daun tetap tegak sehingga membantu penyerapan cahaya matahari yang berguna pada proses pembentukan klorofil.Menurut Dwidjoseputro (1980) Cahaya matahari sangat mempengaruhi proses biosintesis klorofil, cahaya diperlukan untuk pembentukan cincin kelima (cincin E) oleh siklisasi salah satu rantai samping asam propionat menjadi protoklorofil dan untuk mereduksi protoklorofil menjadi klorofil a. Perbedaan warna daun antar perlakuan dapatdilihat pada Gambar 1 tanaman yang diberi perlakuan pupuk nanosilika memiliki warna daun yang lebih hijau dibandingkan dengan perlakuan tanpa pupuk nanosilika. Tanaman pada perlakuan P3 memiliki warna daun yang paling hijau karena memiliki kandungan klorofil a dan klorofil b lebih tinggi dari tanaman lainnya, sedangkan pada perlakuan P0 yang memiliki kandungan klorofil a danklorofil $b$ terendah daunnya berwarna hijau muda kekuningan.Namun pada uji statistik pada taraf signifikansi $95 \%$ perlakuan nanosilika tidak menunjukkan peningkatan yang berbeda nyata

Kandungan klorofil a dan klorofil b pada tanaman mempengaruhi proses pertumbuhan dan perkembangan. Semakin banyak kandungan klorofil a dan klorofil b maka laju fotosintesis akan meningkat, sehingga membuat penyerapan nutrisi dari dalam tanah menjadi lebih optimal dan akan memacu pertumbuhan dan perkembangan tanaman.Menurut Campbell (2010) klorofil a dan klorofil b sangat baik menyerap spektrum merah. Spektrum merah dengan panjang gelombang 630 $675 \mathrm{~nm}$ ini nanti dimanfaatkan untuk menghasilkan energi dalam proses fotosistem I dan fotosistem II. Energi yang dihasilkan akan digunakan untuk proses pertumbuhan.

Hasil tinggi tanaman pada Tabel 2 menunjukkan bahwa pemberian pupuk nanosilika pada tanaman padi hitam dapat meningkatkan tinggi tanaman. Perlakuan P1, P2, P3 dan P4 menunjukkan pengaruh yang nyata terhadap kontrol. Pemberian pupuk nanosilika dapat meningkatkan tinggi tanaman sebesar 33\% dibandingkan dengan kontrol. Hal ini dikarenakan terjadi peningkatan efesiensi fotosintesis akibat keberadaan silika dalam tanaman yang menyebabkan penyerapan unsur hara menjadi lebih optimal.

Silika yang terakumulasi pada daun menyebabkan daun menjadi lebih tegak dan merentang dengan baik akibatnya permukaandaun lebih banyak mendapat sinar matahari sehingga penyerapan cahaya matahari untuk fotosintesis menjadi lebihoptimal.Fotosintat yang dihasilkan akan digunakan untuk proses pertumbuhan seperti 
pemanjangan batang. Selain itu, pemberian silika juga dapat membuat sistem perakaran menjadi lebih baik, sehingga penyerapan unsur hara menjadi lebih optimal. Unsur hara ini akan digunakan dalam proses metabolisme pada tanaman sehingga akan memacu pertumbuhan. Sejalan dengan pendapat Makarim dkk, (2015) yang menyatakan bahwa $\mathrm{Si}$ didalam tanaman menyebabkan perakaran tanaman lebih kuat sehingga penyerapan nutrisi menjadi lebih intensif. Hal ini mempertegas pernyataan Husnain (2011) bahwa suplai Si dapat meningkatkan translokasi $\mathrm{P}$ ke malai sehingga peran $\mathrm{P}$ lebih optimal bagi tanaman.
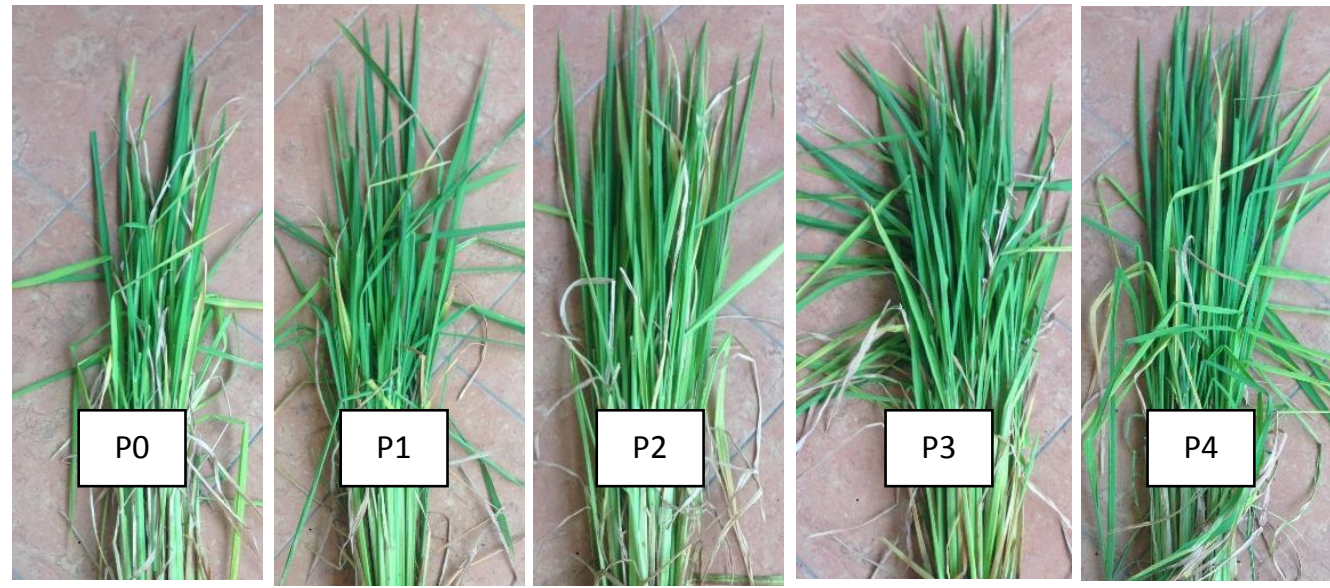

Gambar 1. Perbedaan warna daun tanaman padi hitam antar perlakuan

Hasil jumlah anakan pada Tabel 2 menunjukkan bahwa pemberian pupuk nanosilika dapat meningkatkan jumlah anakan, namun hasil analisis pada taraf signifikansi $95 \%$ menunjukkan tidak beda nyata. Hal ini dikarenakan pemberian silika dapat meningkatkan serapan unsur hara oleh akar terutama unsur $\mathrm{P}$ yang berperan dalam pembelahan sel sehingga dapat memacu pembentukan anakan. Peningkatan serapan unsur hara terjadi karena keberadaan silika pada tanaman dapat membuat sistem perakaran membaik, akar menjadi lebi kuat dan lebih panjang sehingga lebih efektif dalam menyerap unsur hara.

Menurut Winarso (2005) fosfor berperan dalam proses fotosintesis, respirasi, transfer, penyimpanan energi, pembelahan sel dan pembesaran sel. Hasil penelitan Zulputra dkk, (2014) menunjukkan bahwa jumlah anakan padi meningkat dengan meningkatnya serapan $\mathrm{P}$ akibat pemberian silika dikarenakan fosfor dibutuhkan tanaman dalam proses pembelahan sel dan sebagai energi dalam setiap proses metabolisme tanaman.

Pembentukan anakan pada semua perlakuan dipengaruhi oleh beberapa faktor yaitu jarak tanam dan jumlah bibit yang ditaman per lubang. Jumlah bibit dan jarak tanam berpengaruh terhadap jumlah anakan yang kaitannya dengan persaingan dalam penyerapan nutrisi. Semakin banyak bibit yang ditanam perlubang dan jarak tanam yang sempit maka akan semakin sedikit pula jumlah anakan yang akan terbentuk.

Hasil bobot basah dan bobot kering pada Tabel 2 menunjukkan bahwa pemberian pupuk nanosilika dapat meningkatkan bobot basah dan bobot kering tanaman, namun hasil analisis pada taraf signifikansi $95 \%$ menunjukkan tidak beda nyata. Pertumbuhan dan perkembangan tanaman ditunjukkan dengan bertambahnya ukuran dan jumlah sel, hal inilah yang mempengaruhi bobot tanaman. Meningkatnya jumlah anakan dan tinggi tanaman akibat pemberian silika menyebabkan bobot basah dan bobot kering tanaman padi hitam yang diberi perlakuan silika lebih tinggi dibandingkan dengan perlakuan kontrol. Menurut Harjanti dkk, (2013) meningkatnya pertumbuhan anakan akan berpotensi dalam menghasilkan bobot tebu yang optimal 
Pemberian silika dapat meningkatkan serapan unsur hara lain oleh akar terutama unsur $\mathrm{P}$ yang mempengaruhi tinggi tanaman dan jumlah anakan. Selain itu, silika juga dapat meningkatkan efisiensi fotosintesis sehingga fotosintat yang dihasilkan menjadi lebih banyak dan mempengaruhi bobot tanaman padi hitam. Fotosintat akan didistribusikan dan disimpan ke organ vegetatif tanaman seperti akar, batang dan daun sebagai cadangan makanan, penyimpanan cadangan makanan inilah yang akan mempengaruhi bobot basah dan bobot kering tanaman.

Hasil tebal daun pada tabel 2 menunjukkan bahwa pemberian pupuk nanosilika pada tanaman padi hitam dapat meningkatkanTebal daun.Perlakuan P2 dan P3 menunjukkan pengaruh yang nyata terhadap kontrol. Pemberian pupuk nanosilika dapat meningkatkan tebal daun sebesar $100 \%$ dibandingkan dengan kontrol. Hal ini berkaitan erat dengan adanya pembentukan lapisan silika pada daun tanaman.

Silika yang banyak terdapat pada daun tanaman akan terakumulasi di dinding sel dan kutikula membentuk lapisan silika. Di bawah kutikula, silika akan berasosiasi dengan selulosa sehingga menyebabkan lapisan silika (silica layer) tersebut menjadi lebih tebal sehingga dapat meningkatkan tebal daun. Menurut Yoshida et al.(1962) akumulasi silika didaun akan membentuk lapisan cuticle-silica double layer yang terletak diantara kutikula dan dinding sel epidermis

Lapisan silika gel yang tebal membuat daun lebih kuat, kokoh dan merentang dengan baik sehingga penyerapan cahaya matahari menjadi lebih optimal dan laju fotosintesis dapat meningkat. Menurut Yoshida (1985) ketegaran daun padi akibat pemberian silika meningkatkan fotosintesis sebesar 10\% lebih tinggi dari tanaman padi yang tidak diberi silika. Meningkatnya laju fotosintesis akan meningkatkan serapan unsur hara dari dalam tanah sehingga dapat memacu pertumbuhan tanaman.

\section{KESIMPULAN}

Aplikasi pupuk nanosilika pada tanaman padi hitam dengan konsentrasi $7,5 \mathrm{ml} / \mathrm{L}$ dapat meningkatkan jumlah stomata sebesar $142 \%$, tinggi tanaman sebesar $33 \%$ dan tebal daun sebesar $100 \%$ dibandingkan dengan kontrol. Namun pemberian pupuk nanosilika tidak berpengaruh nyata terhadap jumlah anakan, bobot basah, bobot kering dan kandungan klorofil.

\section{DAFTAR PUSTAKA}

Amrullah. 2015. Pengaruh Nano Silika Terhadap Pertumbuhan, Respon Morfofisiologi Dan Produktivitas Tanaman Padi (Oryza Sativa). Disertasi. Sekolah Pasca Sarjana, IPB. Bogor.

Arista, Y., K. A. Wijaya dan Slameto. 2015. Morfologi Dan Fisiologi Dua Varietas Tebu (Saccharum Officinarum L.) Sebagai Respon Pemupukan Silika. Berkala Ilmiah Pertanian.

Aryanto Y. 2012. Nano Technology in Agriculture. Workshop Peluang Nano Teknologi untuk Pertanian. Bogor

Avila F.W., Baliza D.P., Faquin V., Araujo J. and Ramos S.J. 2010.Silicon Nitrogen Interaction In Rice Cultivated Under Nutrient Solution. Revista Ciencia Agronomica, 41: 184-190.

Campbell, N.A., J.B. Reece., dan L.G. Mitchell. 2000. Biologi. Penerbit Erlangga. Jakarta.

Dwidjoseputro, D. 1978. Pengantar Fisiologi Tumbuhan. PT. Gramedia. Jakarta.

Harjanti, R.A., Tohari, S. N. H Utami. 2013. Pengaruh Takaran Pupuk Nitrogen Dan Silika Terhadap Pertumbuhan Awal Tebu (Saccharum officinarum L.Pada Inceptisol. Vegetalika, 3(2): 35-44.

Husnain. 2011. Sumber Hara Silika Untuk Pertanian. Warta Penelitian dan Pengembangan Pertanian, 33(3), pp. 12-13. 
Kristamtini. 2009. Mengenal Beras Hitam Dari Bantul. Artikel Tabloid Sinar Tani. BPTP Yogyakarta.

Makarim, A. K. , E. Suhartatik, dan A. Kartohardjono. 2007. Silikon: Hara Penting pada Sistem Produksi Padi. Iptek Tanaman Pangan. 2(2):195-204.

Ningsih, E. P. , Irfan, D. P. , Diah, R. dan Retno P. S. 2012. Laju Fotosintesis Dan Kandungan Klorofil Kedelai Pada Media Tanam Masam Dengan Pemberian Garam Aluminium. Jurnal AGROTROP, 2(1): 1724

Saeni, M. S. 2010. Pengaruh Pemupukan Silika terhadap Penyerapan Hara Fosfat Pada Tanaman Padi.Jurusan Kimia FMIPA IPB, Bogor.

Suhartini, T dan D. Suardi. 2010. Potensi Beras Hitam Lokal Indonesia. Warta Penelitian dan Pengembangan Pertanian 32(1):9-10.

Wangiyana, W., Z. Laiwan dan Sanisah. 2009. Pertumbuhan dan Hasil Tanaman Padi Var. Ciherang dengan Teknik Budidaya "SRI (System of Rice Intesification)" pada Berbagai Umur dan Jumlah Bibit per Lubang Tanam.Crop Agro. Vol 2 No. 1.

Winarso, S. 2005. Kesuburan Tanah. Penerbit Gava Media. Yogyakarta.

Yoshida, S., Y. Ohnishi and K. Kitagishi. 1962. The Presence Of Cuticle-Silica Double Layer In The Epidermal Tissue. Soil Science And Plant Nutrition Volume 8, Number 2.

Yoshida, S. 1985. The Physiology Of Silicon In Rice. FFTC-ASPAC. Techn. Bull. 25:1-27.

Zulputra, Wawan dan Nelvia. 2014. Respon Padi Gogo (Oryza Sativa L.) Terhadap Pemberian Silikat dan Pupuk Fosfat Pada Tanah Ultisol. Jurnal Agroteknologi, Vol. 4 No. 2: 1-10. 